Revista de Psicología Vol. 35 (2), 2017 (ISSN 0254-9247)

\title{
Behavioral Therapy: a study of the themes of the session
}

\author{
Vagner Angelo Garcia ${ }^{1}$, Alessandra Turini Bolsoni-Silva ${ }^{2}$, \\ Glaucia Fernanda Galeazzi Nobile ${ }^{3}$ \\ Universidade Estadual Paulista - Brazil
}

\begin{abstract}
Social Anxiety Disorder is characterized as an anxiety disorder without spontaneous remission, which causes numerous impairments in the lives of those affected. This study aimed to describe, in terms of frequency and duration, the themes present in behavioral therapy sessions of consultations with university students with social anxiety. The study participants were two clients diagnosed with the disorder and a therapist. The sessions were videotaped and categorized according to the theme of the session. The results were grouped according to the moment of the therapy: Beginning, Development and Termination. The study made it possible to evaluate the implementation of the procedure adopted and the themes that were developed with greater emphasis, relating the diagnosis to the complaints of the client. Keywords: social anxiety, behavioral therapy, therapist-client interaction, university students, session theme.
\end{abstract}

\section{La terapia conductual: un estudio de temas de las sesiones}

El trastorno de ansiedad social se caracteriza como un trastorno de ansiedad sin remisión espontánea que implica numerosos daños en las vidas de sus pacientes. Este trabajo se propone describir, en términos de frecuencia y duración, los temas presentes en las sesiones de terapia comportamental con estudiantes universitarios con ansiedad social. Los participantes fueron dos clientes diagnosticados con el trastorno y un terapeuta. Las sesiones fueron grabadas en vídeo y categorizadas de acuerdo con el tema de la sesión. Los resultados se agruparon de acuerdo a la época de la terapia: Inicio, Desarrollo y Cierre. Esta investigación nos permitió evaluar la ejecución del procedimiento adoptado y qué temas se abordaron con mayor énfasis, relacionando el diagnóstico con las quejas de los clientes.

1 MSc. in Psychology of Development and Learning. Clinical Psychologist of Universidade Estadual Paulista (Unesp). Postal Address: Avenida México, 451 Jardim Aclimação - Pirajuíl SP CEP 16.600-000, Brazil. Contact: vagner_asp@hotmail.com

$2 \mathrm{PhD}$. in Psychology. Associate Professor of the Universidade Estadual Paulista (Unesp), Brazil. Postal Address: Av. Eng. Luiz Edmundo Carrijo Coube, 14-01 - Vargem Limpa, Cep: 17033-360 - Bauru - SP Brazil. Contact: bolsoni@fc.unesp.br.

3 MSc. in Psychology of Development and Learning. Clinical Psychologist of the Universidade Estadual Paulista (Unesp). Postal Address: Av. Eng. Luiz Edmundo Carrijo Coube, 14-01 Vargem Limpa, Cep: 17033-360 - Bauru - SP Brazil. Contact: glau_fgn@hotmail.com 
Palabras clave: trastorno de ansiedad social, terapia conductual-analítica, interacción terapista-cliente, estudiantes universitarios, tema de la sesión.

\section{Terapia Comportamental: um estudo dos temas da sessáo}

O Transtorno de Ansiedade Social é caracterizado como um transtorno de ansiedade, sem remissão espontânea que acarreta inúmeros prejuízos a vida de seus portadores. Este trabalho se propôs a descrever em termos de frequência e duração os temas presentes em sessões de terapia comportamental no atendimento com universitários com transtorno de ansiedade social. Participaram da pesquisa dois clientes diagnosticados com o transtorno e uma terapeuta. As sessōes foram gravadas em vídeo e categorizadas de acordo com a temática da sessão. Os resultados foram agrupados de acordo com o momento da terapia: Início, Desenvolvimento e Encerramento. A pesquisa possibilitou avaliar a execução do procedimento adotado, avaliar quais temas foram trabalhados com maior ênfase, relacionando o diagnóstico com as queixas do cliente.

Palavras-chave: transtorno de ansiedade social, terapia comportamental, interaçáo terapeutacliente, estudantes universitários, tema da sessão. 
The therapeutic process, from a behavioral perspective, should lead the client to develop repertoires for handling different contingencies (Skinner, 1978), as well as to develop skills of self-observation and selfknowledge that assist in identifying, describing and managing relevant variables (Scaini, Belotti, Ogliari \& Battaglia, 2016; Sturmey, 1996). How this is done is, however, a complex question, which involves several steps, including welcoming the client, information collection, formulation of objectives/procedures, refinement of assumptions, evaluation of the procedures used and the formation of the therapeutic bond (Gavino, 1996). The area of research that investigates how these changes and steps occur is called process studies (Zamignani \& Meyer, 2007).

Several researchers have studied the conversation between the therapist and client during the sessions that make up the therapeutic process, classifying this interaction into themes (Baptistussi, 2001; Barbosa, 2006; Garcia, 2001; Hjeltnes et al., 2016; Khatri et al., 2014; Yano, 2003; Zamignani \& Andery, 2005). Despite different aims (using the analysis of thematic categories), researchers have developed studies in which it was possible to characterize and evaluate the therapeutic process, as well as to evaluate the practice of the therapist.

One difficulty in relation to studies on the content of the sessions is that the themes are created from the analysis of a specific interaction, making it difficult to establish relationships between these studies (Donadone, 2009; Zamignani, 2007; Zamignani \& Meyer, 2011). Despite the difficulty described, such studies are necessary because through them it is possible, for example, for the therapist to discriminate which themes produce resistance responses in the client, as by describing an event it becomes possible to behave in the most effective way in relation to it (Nardi \& Meyer, 2008). One study, in which a client with chronic pain was the participant (Nardi \& Meyer, 2008), showed that the client responded to different themes according to 
two standards (adherence and resistance). The themes "emotions surrounding the absence of the sister", "social activities" and "professional activities" generated resistance in all their occurrences. In turn, the theme "relationship with parents" produced no resistance or hostility. Accordingly, the authors argue that it is important for the therapist to have prior knowledge about what themes could cause their client to present resistance in order to find the best way to conduct the intervention (Nardi \& Meyer, 2008).

Another study related behaviors of the therapist with a nonpunitive audience (Baptistussi, 2001). The author stated that, if the therapist acquires the function of pre-aversive stimulus related to the report of the client when talking about a particular subject, the likelihood that he will continue talking to the therapist about this subject tends to decrease. The variety of themes covered by the client in the session was also the subject of a study (Garcia, 2001) and was correlated as an indicator of adherence or avoidance responses. A further detail of both studies (Baptistussi, 2001; Garcia, 2001) is that the moment that the client and therapist introduced new themes was also categorized, as well as who changed, derived or started the new topic.

Clients diagnosed with Obsessive-Compulsive Disorder were the focus of a study that sought to characterize the analytical-behavioral therapeutic process in the attendance of this diagnosis, through the vocal analysis of the verbal behavior of the client that related to the description of the complaint (Zamignani \& Andery, 2005). The authors considered that the actions of these therapists seemed to fulfill the specific needs for managing the complaints presented by their respective clients. This study showed how the theme of the session could be exploited in various ways and, in this case, used to verify how the therapist responded to the subject "Description of the complaint" of the client, showing different ways to approach the same subject.

Another use of the categorization of the subject/theme discussed in the session was in the care of post-surgical patients (Starling, 1999), in which verbal episodes were separated into sub-themes and categories created from the analyzed material. Four categories and various sub- 
categories were created. The categories included "clinical episode of the post-surgical period", "social relationships", "everyday life" and a residual category "others". The study highlighted the need for more research, and argued that when we know what the more common themes are in the reports of surgical clients and how these themes vary throughout the hospitalization, the possibility of formulating a more appropriate and effective psychological practice will arise (Starling, 1999).

A similar study aimed to investigate, through verbal reports, the existence of recurring content (that was repeated with consistency) in the behavioral care of people with cancer (Ferreira, Fornazari \& Silva, 2012). The proposal of the study was collaboration for the planning of interventions that contribute to improving the quality of life of cancer patients. The themes were subsequently defined, which enabled a characterization of the care for this population.

Evaluations of results are also possible in studies related to the theme (Donadone, 2009; Yano, 2003). In the care for clients diagnosed with panic disorder (Yano, 2003), the categorization was performed around events deemed relevant (theme) for this disorder, and the results made it possible to correlate themes and the scope of the goals of the therapy.

One of the aims of an investigation into guidance and self-guidance in behavioral interventions (Donadone, 2009) was to determine whether there was a correlation between the presence of guidance/selfguidance and the theme of the session. The researcher concluded that a slight relationship existed, and that therapists can provide guidance when presented with all the themes of the session (Donadone, 2009; Meyer, 2009). The most common themes were Interpersonal Relationships (55\%), which included several sub-themes, such as Relationships with spouse/partner with parents/stepparents, with family members and other relationships, Psychiatric and Psychological Complaints (22\%), Work/Study and/or Career (13\%), Physiological Problems (7\%) and Other Themes (3\%) (Donadone, 2009).

Zamignani developed a Multidimensional Categorization System of the Behavior in the Therapeutic Interaction (SiMCCIT) (Zamignani, 2007). The system was developed on three axes: verbal behavior (I), 
themes (II) and motor responses (III). In this work, we will focus on Axis II, which offers suggestions for categories and their definitions (Zamignani, 2007). However, in the work of Zamignani there is only the description of the session themes, as the author did not present any research using this. The study on guidance and self-guidance (Donadone, 2009), which used the themes of the SiMCCIT, is apparently the most complete work on thematic categories.

All research related to the theme (subject) of the session is likely to have some particularities: what the intervention itself is, that is, for whom the therapy is intended (target audience), which intervention model is proposed, among others. In this work, the study of themes is related to interventions with university students with Social Anxiety Disorder.

The studies presented demonstrate the potential uses of the theme of the session for the study of the therapeutic interaction, with the theme understood by reporting behaviors (of the client and therapist) which are grouped into classes/categories (functional/equivalent). Thus, it is possible to describe how a therapy session occurs, what the most frequent themes are and to relate them to the complaint of the client, as well as to develop and conduct procedures from relevant themes that make greater participation of the client possible. The theme of the session may also be useful for evaluating the results of the therapy and whether certain themes cause avoidance of the client or suggest evolution of the therapeutic process. However, no studies have investigated what the most frequent themes would be in the care for people with social anxiety.

\section{Social anxiety disorder and the therapeutic interaction}

Social Anxiety Disorder (SAD) is characterized as a state of intense and persistent fear presented by a person when exposed to certain social situations (e.g., eating, writing, public speaking, interacting with the opposite sex), fearing that they will behave in a humiliating or embarrassing way and/or receive disapproval or rejection by their peers (APA, 2002; Falcone, 1998; Spence \& Rapee, 2016). This behavioral pattern 
of avoidance of social situations causes impairments in the professional, academic and social life of the individual (Falcone, 1998; Rocha, 2012).

The Diagnostic and Statistical Manual of Mental Disorders DSM-V (APA, 2013) was recently launched in the United States. It has some differences to the DSM-IV-TR (APA, 2002) in relation to the characterization of SAD. The first relates to the nomenclature, where social phobia is now referred to as Social Anxiety Disorder (SAD). Another change is in relation to the symptoms, where now the symptoms must have a minimum duration of six months or more for the diagnosis (previously the period was only a requirement for the diagnosis in children). The minimum period for presence of symptoms reduces the possibility that an individual is experiencing only a transitory or temporary fear.

Social Anxiety Disorder causes a debilitating condition and has a low remission rate, with this being the most common anxiety disorder (Hjeltnes et al., 2016; Rocha, 2012). Its lifetime prevalence is $12.1 \%$ and, in clinical samples, patients with social anxiety disorder represent 10-20\% of individuals with anxiety disorders (Kessler et al., 2005).

University students diagnosed with Social Anxiety underwent a behavioral intervention with social skills training that aimed to evaluate the efficacy of the procedure adopted (Rocha, 2012). The themes discussed at the meetings were described in the informative booklet "How to face the challenges of the university" (Bolsoni-Silva, 2009), these being: 1) Presentation, verification of expectations; 2) Communication: begin and maintain conversations; 3) Communication: asking and answering questions; 4) Know basic human rights; 5) Know differences between skilled, active unskilled and passive unskilled behavior; 6) Expressing positive feelings, praising; 7) Giving and receiving positive feedback, thanking, expressing opinions (of agreement, disagreement), listening to opinions (of agreement, disagreement); 8) Expressing negative feelings, giving and receiving negative feedback, requesting changes in behavior; 9) Dealing with criticism (giving and receiving criticism), admitting mistakes made, apologizing; 10) Loving relationship; 11) Family relationship, and 12) Public speaking. 
Rocha et al. (2013) pointed out that although each session eschews a basic theme, the intervention was conducted in accordance with the particularity of each client, as the procedure was semi-structured and adapted to the needs of each participant.

To focus the content is an alternative that can be and is increasingly used by many researchers who study different aspects related to verbal behavior (Donadone, 2009). However, the predominance of a theme depends upon a number of variables, such as the need to discuss certain content presented by the client; the analysis of contingencies by the therapist; therapeutic procedures; modeling of the verbal repertoire of the client (reports/content that the therapist reinforces, punishes, puts into extinction) and of the therapist (who's reports remain or are extinct from the interaction with the client) (Donadone, 2009).

Given this context, it is questioned whether there are regularities in working with certain themes in the care for clients diagnosed with SAD. It is assumed that due to the nature of this disorder the Interpersonal Relationship theme should be the most frequent in interventions with this population. However, other themes may also arise, as social anxiety disorder can be diagnosed due to the response of an individual in a variety of social situations; for example, dating, study and work. Thus, the aim of this study was to describe, in terms of frequency and duration, the themes present in behavioral therapy sessions with university students with SAD, and to investigate whether there were different interactions between the two clients regarding the frequency data.

\section{Method}

The design of the study was a single subject case study. Using this method, it is possible to evaluate the changes through which the subject passes, with the subject him/herself as the control. Skinner (1966) stated that it was preferable to study one subject for a thousand hours than a thousand subjects for one hour. In this sense, Sidman (1960) states that single subject designs require that the behavior of the same 
Behavioral Therapy: a study of the themes of the session / García et al.

individual is measured continuously and repeatedly throughout the experiment. Therefore, the issues discussed during the therapy session is analyzed according to each of the participants.

\section{Participants}

The participants were one psychologist and two clients. The therapist had graduated three years previously and practiced from the perspective of Behavior Analysis during this time. The clients were university students and fulfilled the diagnostic criteria for SAD, without comorbidities. Participant 1 (P1) was male, aged 19 , attending the $2^{\text {nd }}$ year of the Undergraduate Course in Computer Science, was unmarried, without a girlfriend, did not work and resided in shared student accommodation with a friend. Participant 2 (P2) was female, aged 22 years, attending the $4^{\text {th }}$ year of Pedagogy, was unmarried, with a boyfriend, did not work, but was performing the curricular internship and resided in shared student accommodation with four friends.

Both clients underwent a behavioral intervention procedure (individual) which included social skills training, applied in 12 sessions (Bolsoni-Silva, 2009; Rocha, 2012). The sessions were videotaped, and the clients and therapist signed an Informed Consent form (IC Appendix) authorizing the use of the footage according to Resolution 196/96 of the CNS, with the study being approved by the Research Ethics Committee of the University to which it was linked. The sessions were conducted in the Applied Psychology Center of a University in the state of São Paulo, Brazil.

\section{Measures}

Video files were used, which contained recordings of the therapy sessions (11 sessions for each participant), totaling $38 \mathrm{~h} 15 \mathrm{~min}$ of analysis, with an average time of each session around 100min (varying from 50 to 120 minutes). Axis II-1 of the Observation Protocol was also used, containing the session theme categories (Zamignani, 2007). 
The thematic categories suggested by Zamignani and used in this work were: (1)Therapeutic relationship, (2)Relationships with spouse/partner, (3)Relationships with children or stepchildren, (4) Relationships with parents or stepparents, (5)Relationships with other family members, (6)Work, (7)Study and/or career, (8)Religion, (9) Interpersonal relationships, (10)Feelings in general, (11)Judgments or tendencies for action, (12)Existential questions, (13) Traumatic events, (14)Fantasy activity or game, (15)Development of techniques/procedures or interviews, (16)Psychiatric complaints and medical symptoms, and (17)Other issues (Zamignani, 2007).

\section{Procedure}

The sessions were categorized by the researcher and an assistant (called the Observers), both being graduates in Psychology, the assistant having a year of experience in behavioral therapy (curricular internship). The Observer XT software was used to analyze the sessions, with the SPSS (version 17.0) statistical program used to analyze the data. Data collection was carried out in three stages as described below:

- Stage I - Study and Consensus: this step consisted of the study and discussion of the themes proposed in Axis II (Session themes) of the Multidimensional System for the Categorization of Behavior in the Therapeutic Interaction - SiMCCIT (Zamignani, 2007). The first moment of study and discussion of the categories by the observers was followed by a second moment in which the aim was to analyze the degree of concordance between them for the use of the proposed system. For this analysis, two indicators were used: Concordance Percentage (CP) and Kappa index (K). First, 30 minutes of one session were randomly selected and categorized according to the SiMCCIT (Zamignani, 2007), in order to verify whether the index was within the satisfactory limits: Concordance Percentage (CP) over 70\% (Fagundes, 2015) and Kappa Coefficient (K) above .60 (Fonseca et al., 2007). 
The ratio obtained for these first 30 minutes of analysis was highly satisfactory $(\mathrm{CP}=94 \% / \mathrm{K}=.94)$, which allowed the observers to continue to the next stage to obtain the final concordance index.

- Stage II - Concordance between Observers: after study and consensus of the observers regarding the use of SiMCCIT Axis II (Zamignani, 2007), 20\% of the sessions were randomly selected for analysis ( 4.4 sessions, rounded up to 5 sessions), with the aim of evaluating the final concordance index between the observers (Kazdin, 1982). This step differed from the previous one since there was no communication between the observers. The five randomly selected sessions and their levels of concordance were:

$$
\begin{aligned}
& \text { o } \quad \text { 1 session 01: } \mathrm{CP}=81 \% / \mathrm{K}=.79 \\
& \text { o } \quad \mathrm{P} 1 \text { session 10: } \mathrm{CP}=79 \% / \mathrm{K}=.78 \\
& \text { o } \mathrm{P} 1 \text { session 11: } \mathrm{CP}=81 \% / \mathrm{K}=.80 \\
& \text { o } \mathrm{P} 2 \text { session 03: } \mathrm{CP}=81 \% / \mathrm{K}=.80 \\
& \text { o } \mathrm{P} 2 \text { session 12: } \mathrm{PC}=85 \% / \mathrm{K}=.84
\end{aligned}
$$

As can be seen, the index maintained a satisfactory level, CP above 70\% (Fagundes, 2015) and K above .60 (Fonseca et al., 2007), with regularity maintained among the sessions.

- Stage III - Categorization of the sessions: after Stage II, the division of the remaining sessions took place for analysis by the observers for the categorization.

After the collection procedure described in the above steps, the data were exported to the SPSS statistical software. The data consisted of the frequencies of each category per session and the duration (in seconds) of each theme and were grouped, according to the intervention period, into three moments: I) Beginning of the Therapy (three initial sessions), II) Development of the Therapy (five intermediate sessions), and III) Termination of the Therapy (three final sessions). In each of these periods the simple arithmetic mean was calculated, thereby 
obtaining an index that would allow a comparison of each moment of the intervention: beginning, development and termination of the therapy. To compare whether there were different interactions with the two clients and the frequency data, the Mann-Whitney U statistical test was performed.

\section{Results}

Table 1 presents data on the mean frequency and respective percentages of the Session Theme categories. The most prominent category for both participants in the beginning and development phases of the therapy was Interpersonal Relationships. At the end of therapy, in the period called Termination, for P2, Interpersonal Relationships remained the most frequent, while for P1 Relationships with Spouse/ Partner had the highest mean.

For both participants at the beginning of the therapy the category of Work, study and/or career presented similar means (11.8 and 11\%, respectively), being the second most prominent category. The category Techniques, interviews and procedures presented a high mean for P1 (11\%), and high, however, lower for P2 (7.7\%), which decreased for both during the Termination of therapy.

Other data that should be highlighted are related to the categories Therapeutic relationship and Relationships with parents/stepparents, which were more frequent at the termination of the therapeutic process than at the beginning for both participants. The same was revealed for the theme Relationships with spouse/partner for P2. Regarding P1, at the beginning and during the development of the therapy, there was the presence of this subject, with an increased frequency at the termination of the process. 


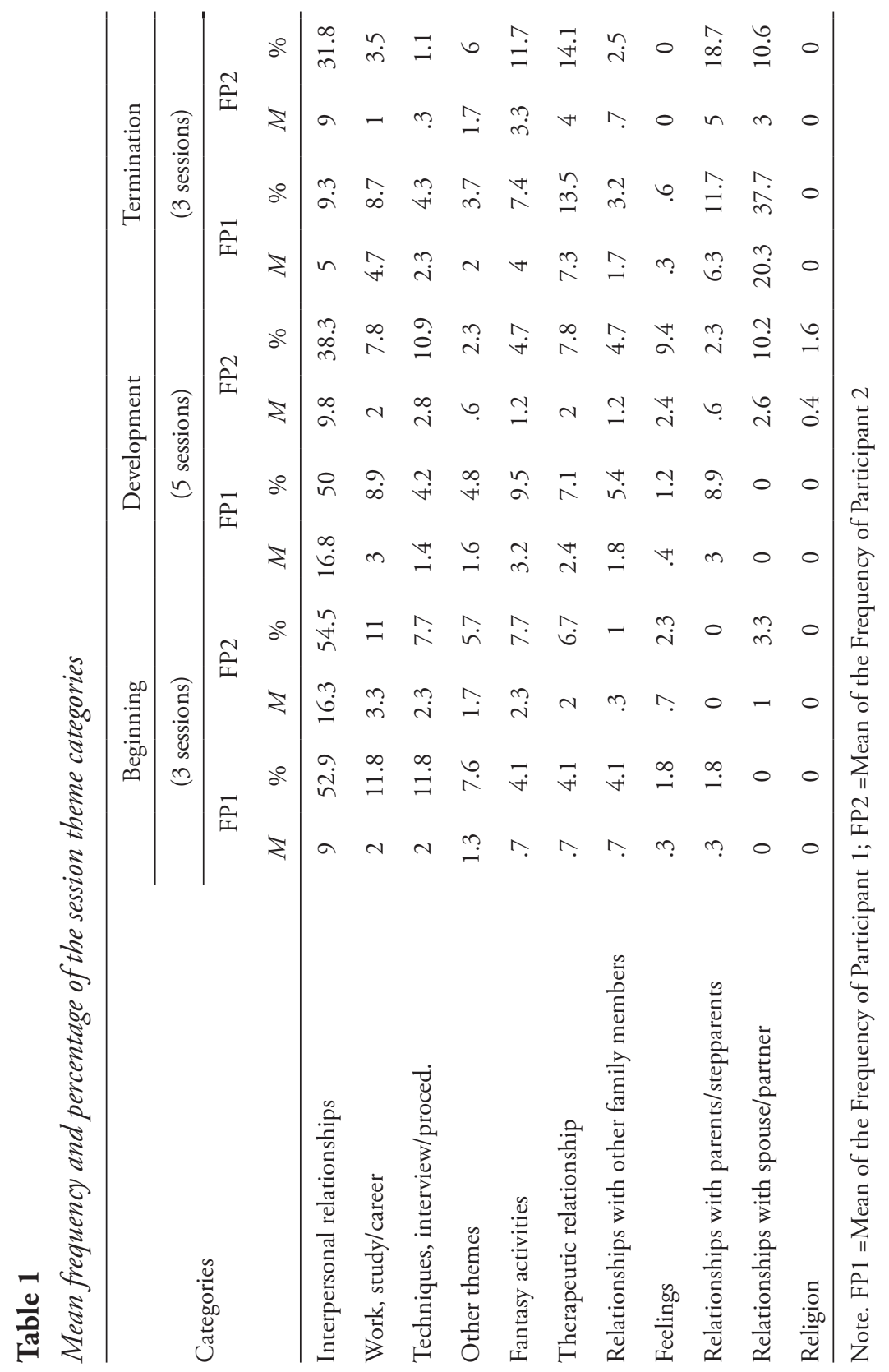


The themes Relationships with other family members, Feelings and Other themes maintained similar means throughout the three phases of the therapy, presenting low frequencies. In turn, Fantasy activities, which included the moments of the application of the behavioral testing technique, increased for P1, and decreased for P2 from the beginning to the development, increasing again during the termination phase.

Table 2 presents the mean duration in seconds and percentages for the categories of the themes, for both participants. Regarding the mean time of each category per session, the one that stood out was Interpersonal Relationships in the Beginning and Development phases of the therapy for both clients, as well as in the Termination phase for $\mathrm{P} 2$. In the final phase of the therapeutic process there was a considerable increase in the category Relationships with spouse/partner for P1, going from a mean of zero to $26.9 \%$.

Generally, the categories of Therapeutic Relationship, Relationships with spouse/partner and Relationships with parents/stepparents showed an increase from the beginning to the end of therapy. Two other categories stand out because, despite low mean frequencies, they presented high duration, these being: Fantasy activities and Techniques, interviews/procedures. The thematic category Work, study and/or career increased for P1 and decreased P2 from the Beginning to the Termination.

Table 3 presents the means and p values (Mann-Whitney U) for the Session Themes categories. Only one category showed a statistically significant difference between the participants, this being Relationships with spouse/partner, with $p=.04$. 


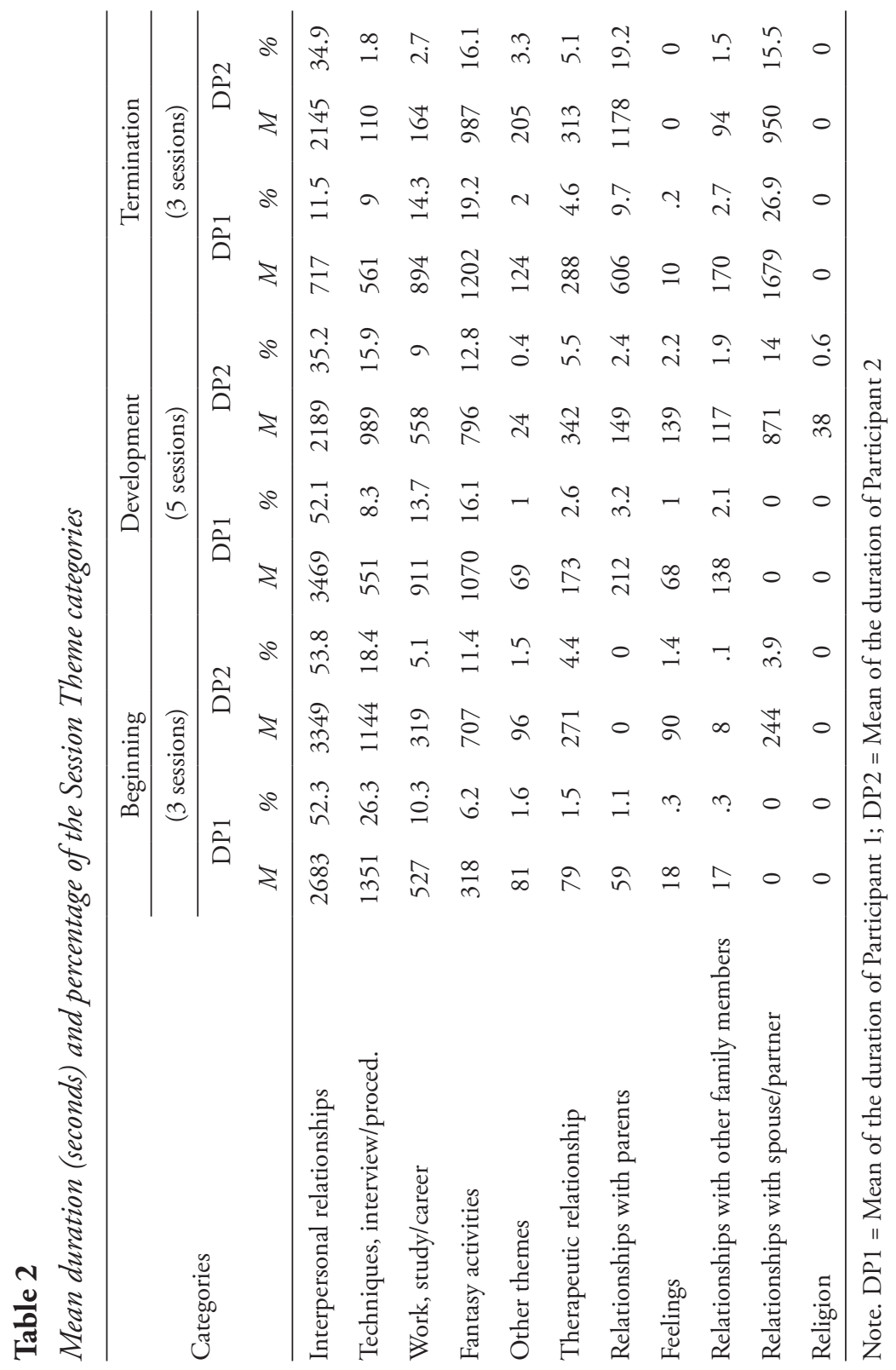




\section{Table 3}

Mean and $p$ value for the Session Themes categories*

\begin{tabular}{lccc}
\hline Categories & $M \mathrm{P} 1$ & $M \mathrm{P} 2$ & $p$ \\
\hline Fantasy activities & 2.73 & 2.09 & .51 \\
Other themes & 1.64 & 1.18 & .39 \\
Therapeutic relationship & 3.27 & 2.55 & .81 \\
Relationships with spouse/partner & 5.55 & 2.27 & $.04^{*}$ \\
Relationships with other family members & 1.45 & .82 & .17 \\
Relationships with parents & 3.18 & 1.73 & .19 \\
Interpersonal relationships & 11.45 & 11.36 & .89 \\
Religion & 0 & .18 & .31 \\
Feelings & .36 & 1.27 & .4 \\
Techniques, Interview/proced. & 1.82 & 2 & .91 \\
Work, study/career & 3.18 & 2.09 & .31 \\
\hline
\end{tabular}

${ }^{*} p<.05$

\section{Discussion}

The Interpersonal Relationships category is characterized by the client's relationships with other subjects outside the session, with the exceptions of family members, loving relationships and professional relationships (Zamignani, 2007). In this study, it was observed that in the beginning and development phases of the therapy Interpersonal Relationships was the most frequent category and had the longest duration (Tables 1 and 2). Donadone (2009) also found this category to be the most frequent (55\%), however, in this study Interpersonal Relationships included other types of relationships, such as relationship with spouse/partner, with parents/stepparents, with family members and other relationships. When these relationships are analyzed separately, a more accurate analysis of the session theme is possible. 
The high index of the Interpersonal Relationships theme analyzed together with the case studies of each participant (Rocha, 2012) demonstrates how much difficulty each client had in their relationships with people outside of their closer lives. This is characteristic of SAD and the data corroborates studies of the area that say it is possible to use the theme of the session to describe the therapeutic process (Zamignani, 2007; Zamignani \& Andery, 2005).

The first three sessions of the intervention (Beginning of the therapy) include the themes of Presentation, verification of expectations; Communication: starting and maintaining conversations, and Communication: asking and answering questions (Rocha, 2012). When presented with this theme, a higher frequency and duration of the category of Interpersonal Relations is expected, since such behaviors are expected in the relationships with friends and colleagues and in encounters with strangers. It is also expected that the participants of the therapy will present deficits in this area. This data shows how the procedure developed was in accordance with the procedure performed, i.e., the therapist tried to work with these behaviors when presented with the difficulties that the client reported. Another assumption is that the study of the session theme enabled the confirmation of the complaint of the client (Zamignani \& Andery, 2005), with the high frequency of the Interpersonal Relationship category being closely related to the social anxiety disorder complaint.

Another important category at the beginning of the therapy was that of Techniques, interviews and procedures, with a high frequency and duration for both clients. This category is characterized by the application of instruments and/or evaluation scales. Comparing the data from the beginning phase of the procedure with that of the termination phase for this category, a decrease in the mean time that each participant used for the discussion of this can be observed. This fact can be explained by the development/enhancement of skills of the client related to identifying their own behaviors in social interactions, which highlights one of the possibilities of the study of therapeutic interaction themes as an aid in evaluating the results of the therapy (Starling, 1999; Yano, 2003). 
The Development phase consisted of five intervention sessions and included the themes: Basic human rights; Skilled, active/passive unskilled behavior; Expressing positive feelings, praise; Giving and receiving positive feedback, thanks; Expressing and listening; Expressing negative feelings, giving and receiving negative feedback, requesting changes in behavior; and Dealing with criticism, admitting mistakes made, apologizing. These themes are broad and expected in many types of relationships: with parents, family members, loving relationships, work/school, etc. In this period of the intervention, Interpersonal Relationships continued to be highlighted over the other categories, with high frequencies and duration for both clients.

During the termination phase of the therapy, the expected themes were Loving and family relationships, and Public speaking. It was observed that in this period the mean frequency and duration increased considerably for the Relationships with spouse/partner category for both clients, with the Relationship with parents and Relationship with family members categories also increasing, however, to a lesser extent. This data shows that the issues discussed at the meetings were consistent with the themes proposed in the procedure.

Another important point is that in the Termination of therapy, there was a difference in the amount of time devoted to the discussion of each theme for the participants. This fact highlights two issues regarding the intervention: the first refers to the flexibility of the procedure and its appropriateness for the complaints of the client (Rocha, 2012) and the second highlights an important aspect of research on the therapeutic interaction, which is the relationship between the content covered during the session and the complaint of the client. For example, P1 had more difficulty in loving relationships than P2, who already had a boyfriend, however, had more difficulties in the relationship with her father than P1. These facts were described in the case study of each participant developed for the intervention (Rocha, 2012) and confirmed by the extent that they were discussed in the sessions with the therapist (P1: 26.9\% for Relations with spouse/ partner and $9.7 \%$ for Relations with parents; P2: 15.5\% for Relations 
with spouse/partner and 19.2\% for Relations with parents - duration data).

This data reflects a relationship with the changes in the DSM-V (APA, 2013), where the term social phobia has now been called Social Anxiety Disorder (SAD). One of the reasons for the change reflects a new and broader understanding of the condition in a range of social situations. In the past, social phobia, was mainly diagnosed if an individual felt discomfort or extreme fear in the presence of strangers. The new DSM shows that this definition is too narrow, and now social anxiety can be diagnosed due to an increase in the frequency of an individual avoiding contact in a variety of social situations, as confirmed here by the themes, in the loving relationship and in the relationship with the parents.

The intervention procedure analyzed included the use of several behavioral techniques, such as modulation, modeling, reinforcement and role-playing (Rocha, 2012). Role-playing allows the client to be taught to describe functional relationships and produce self-awareness when presented with interpersonal problems and difficulty in discrimination of the contingencies in place (Souza, Orti \& Bolsoni-Silva, 2012). In the thematic categories of the SiMCCIT (Zamignani, 2007), role-playing is categorized as part of the Fantasy activities or play theme. One study using the SiMCCIT (Zamignani, 2007) evaluated the effects of a fantasy activity on the therapeutic interaction (Peron \& Silveira, 2013). The results of this study suggest that the fantasy activity influenced some categories for the therapist and client, such as interpretations, providing information, recommendations, establishing relationships between events, reporting improvement or therapeutic progress and formulation of goals, highlighting the importance of this technique in the therapeutic process.

In the present study, it can be observed that during the three phases of the intervention the application of the role-playing technique and other fantasy activities occurred and that as the therapy progressed, the time devoted to its implementation increased (from $6.2 \%$ to $19.2 \%$ for P1 and from $11.4 \%$ to $16.1 \%$ for P2). This demonstrates that, 
with the course of the discussion of the proposed themes (BolsoniSilva, 2009), the therapist spent more time teaching/training these behaviors. It can be observed that, after the termination of the procedure and post-test measures, both participants no longer met the diagnostic criteria for Social Anxiety Disorder, according to the instruments used (Rocha, 2012). It is probable that this improvement was influenced by the training that occurred during the application of the role-playing technique, gradually extended (frequency and duration) according to the advance in the contents developed.

The Therapeutic Relationship category was categorized when the issue was related to events that occurred in the session, in the therapistclient interaction, or when it concerned feelings or impressions of the therapist or client, with respect to one another (Zamignani, 2007). Referring again to the intervention model used (Rocha, 2012), it was observed that at the end of each session the therapist asked the client to give an oral or written Performance Evaluation, with the performance of each (therapist and client) and the session structure discussed. In these moments, the Therapeutic Relationship theme was the most common categorization, with the categorization of this theme possibly appearing at other moments, as long as the criteria for the category were fulfilled.

For the university student with social anxiety it is estimated that it is difficult to expose and perform an evaluation/critique of the therapy session. However, over the course of the therapeutic process, it is expected that this ability would be demonstrated, as evidence of improvement. Thus, during the therapy, the categorization of the Therapeutic Relationship theme increased regarding frequency and duration, which is presumably due to the above hypothesis, i.e. the improvement of the client with regard to the diagnosis, with assessments and/or criticism regarding the other starting to be made. This finding is further evidence of how the study of the therapeutic interaction through the session themes can be used as an evaluation of the result of the therapy (Donadone, 2009; Yano, 2003). 
Table 3 shows that there was a statistical difference in the categorization of the themes of the therapeutic dyad for only one category, i.e., almost all of the themes covered in the sessions were equal for P1 and P2. This data differs from those presented in other studies (Zamignani \& Andery, 2005), which described different practices of the therapist when presented with clients with the same diagnosis. The theme that presented differences between the participants was that of Relationship with spouse/partner, which can be explained by the description of the participants, where P2 had a boyfriend and P1 was single. For this reason, it was expected that there would be moments in the therapy when P2 would want to discuss her loving relationship, an area that would not be covered by P1.

This study found a broad relationship between the themes described and the diagnosis and complaint of the participants, i.e., Social Anxiety Disorder and relationship difficulties with housemates and university colleagues. This fact was evidenced in the mean frequency and duration of the themes (Tables 1 and 2), where social anxiety was represented in many different instances of the life of each participant, for example, in relationships with friends/colleagues (interpersonal relationships), in issues related to work/studies and/or career, in loving relationships (relationships with spouses/partners) and in relationships with other family members.

Some statements from the few studies that have aimed to describe the therapeutic interaction in terms of subjects/themes covered in the interaction were confirmed here. For example, the use of this type of study to evaluate the performance of the proposed intervention (Donadone, 2009; Yano, 2003), to evaluate which themes are developed with greater emphasis relating to the diagnosis of the client (Zamignani \& Andery, 2005), to verify the application of techniques and questionnaires, and the time spent on each category to assist in the formulation of the procedure (Ferreira et al., 2012; Starling, 1999).

This study allowed the description, in terms of categories, of the themes that were discussed during behavioral therapy sessions in consultations with university students with Social Anxiety Disorder. 
A limitation in the discussion of the results relates to the limited number of existing studies on the themes of the session, which makes comparisons difficult. This knowledge gap regarding the theme of the session highlights the need for further studies aiming to assess whether the themes described in this study are also evident in the treatment of other diagnoses.

Regarding the performance of new studies, it is suggested that the theme of Interpersonal Relations could be divided into other subthemes, in order to better describe and explore the subject. In the case of care for people with social anxiety, a suggestion would be to describe the subjects that this theme addresses, for example, strangers, friends, colleagues, and others.

Conducting further studies on themes of the session would allow the mapping of how the behavioral therapy sessions occur, which would help in the development of procedures and the training of future therapists. Considering that knowing how a therapy session is conducted is essential for the learning of new therapists, the description of the themes would assist in this process.

\section{References}

American Psychiatric Association (2002). DSM-IV-TR - Manual diagnóstico e estatístico de transtornos mentais. Porto Alegre: Editora Artmed.

American Psychiatric Association (2013). Diagnostic and Statistical Manual of Mental Disorders, Fifth Edition. Washington, DC: Author. https://doi.org/10.1176/appi.books.9780890425596

Baptistussi, M. C. (2001). Comportamentos do terapeuta na sessão que favorecem a redução de efeitos supressivos sobre comportamentos punidos do cliente. Master Dissertation, Universidade Católica de São Paulo, São Paulo.

Barbosa, J. I. C. (2006). Análise das funçôes de verbalizaçôes de terapeuta e cliente sobre sentimentos, emoçóes e estados motivacionais na 
Behavioral Therapy: a study of the themes of the session / García et al.

terapia analitico-comportamental. Thesis, Universidade Federal do Pará, Belém.

Bolsoni-Silva, A. T. (2009). Como enfrentar os desafios da universidade. São Carlos: Suprema.

Donadone, J. C. (2009). Análise de contingências de orientaçôes e autoorientaçóes em intervençôes clinicas comportamentais. Thesis, Instituto de Psicologia, Universidade de São Paulo.

Fagundes, A. J. F. M. (2015). Descrição, definição e registro de comportamento. São Paulo: Edicon.

Falcone, E. M. O. (1998). Fobia social. In B. Rangé (Org.), Psicoterapia comportamental e cognitiva (pp. 133-149). Campinas: Editorial Psy.

Ferreira, R. R., Fornazari, S. A. \& Silva, W. R. (2012). Conteúdos recorrentes no relato verbal de pessoas com câncer: uma possibilidade de análise com vistas à prevenção. In C. V. B. B. Pessôa et al. (Orgs.), Comportamento em foco (pp. 191-202). São Paulo: Associação Brasileira de Psicologia e Medicina Comportamental.

Fonseca, R., Silva, P. \& Silva, R. (2007). Acordo inter-juízes: O caso do coeficiente kappa. Laboratório de Psicologia, 5(1), 81-90.

Garcia, M. R. (2001). Uma tentativa de identificação de respostas de esquiva e da utilização do procedimento de bloqueio de esquiva através da análise de uma relação terapêutica. Master Dissertation, Pontifícia Universidade Católica, São Paulo.

Gavino, A. (1996). As variáveis do processo terapêutico. In V. E. Caballo (Org.), Manual de técnicas de terapia e modificação de comportamento (pp. 131-143). São Paulo: Editora Santos.

Hjeltnes, A., Moltu, C., Schanche, E. \& Binder, P. (2016). What Brings You Here? Exploring Why Young Adults Seek Help for Social Anxiety. Qualitative Health Research, 26(12), 1705-1720. https://doi.org/10.1177/1049732315596151

Khatri, N., Marziali, E., Tchernikov, I. \& Shepherd, N. (2014). Comparing telehealth-based and clinic-based group cognitive behavioral therapy for adults with depression and anxiety: a pilot study. Clinical Interventions in Aging, 9(6), 765-786. https://doi. org/10.2147/CIA.S57832 
Kazdin, A. E. (1982). Single-case research designs: Methods for clinical and applied settings. New York: Oxford University Press.

Kessler, R. C., Chiu, W. T., Demler, O., Merikangas, K. R. \& Walters, E. E. (2005). Prevalence, severity, and comorbidity of 12-month DSM-IV disorders in the national Comorbidity Survey replication. Arch Gen Psychiatry, 62(6), 617-627. https://doi. org/10.1001/archpsyc.62.6.617

Meyer, S. B. (2009). Análise de 'solicitação de informação' e 'recomendação' em banco de dados de terapias comportamentais. [Thesis] Instituto de Psicologia, Universidade de São Paulo. São Paulo.

Nardi, R. \& Meyer, S. B. (2008). Proposta de interpretaçâo de operantes verbais na relaçấo terapeuta-cliente, demonstrada em caso de dor crônica. Revista Psicolog, 1(1), 68-87.

Peron, F. \& Silveira, J. M. (2013). Efeitos de uma atividade de fantasia em medidas da interação terapêutica. Revista Brasileira de Terapia Comportamental e Cognitiva 15(1), 20-35.

Rocha, J. F. (2012). Efeitos de uma intervenção comportamental com treino de habilidades sociais para universitários com fobia social. Master Dissertation, Universidade Estadual Paulista, Bauru.

Scaini, S., Belotti, R., Ogliari, A. \& Battaglia, M. (2016). A comprehensive meta-analysis of cognitive-behavioral interventions for social anxiety disorder in children and adolescents. Journal of Anxiety Disorders, August, 42, 105-112. https://doi.org/10.1016/j.janxdis.2016.05.008

Sidman, M. (1960). Tactics of scientific research: Evaluating experimental data in psychology. New York: Basic Books.

Skinner, B. F. (1966). Operant behavior. In W. K. Honig, Operant research: Areas of research and application (pp. 12-32). New York: Appleton-Century-Crofts.

Skinner, B. F. (1978). Sobre o Behaviorismo. São Paulo: Cultrix.

Spence, S. H. \& Rapee, R. M. (2016). The etiology of social anxiety disorder: An evidence-based model. Behaviour Research and Therapy, 86, 50-67. https://doi.org/10.1016/j.brat.2016.06.007 
Souza, V. B., Orti, N. P. \& Bolsoni-Silva, A. T. (2012). Role-playing como estratégia facilitadora da análise funcional em contexto clínico. Revista Brasileira de Terapia Comportamental e Cognitiva 14(3), 102-122.

Starling, R. R. (1999). Observação direta e medidas do comportamento verbal nas intervençóes da enfermidade: Um estudo piloto. Revista Brasileira de Terapia Comportamental e Cognitiva 1(2), 107-124.

Sturmey, P. (1996). Functional analysis in clinical psychology. Chichester: John Wiley \& Suns.

Yano, Y. (2003). Tratamento padronizado e individualizado no transtorno do pânico. Thesis, Universidade de São Paulo, São Paulo.

Zamignani, D. R. (2007). O desenvolvimento de um sistema multidimensional para a categorização de comportamentos na interação terapêutica. Thesis, Universidade de São Paulo, São Paulo.

Zamignani, D. R. \& Andery, M. A. P. A. (2005). Interação entre terapeutas comportamentais e clientes diagnosticados com transtorno obsessivo-compulsivo. Psicologia: Teoria e Pesquisa 21(1), 109-119. https://doi.org/10.1590/s0102-37722005000100015

Zamignani, D. R. \& Meyer, S. B. (2007). Comportamento verbal no contexto clínico: contribuiçóes metodológicas a partir da análise do comportamento. Revista Brasileira de Terapia Comportamental e Cognitiva, 9(2), 241-259.

Zamignani, D. \& Meyer, S. B. (2011). Comportamentos verbais do terapeuta no Sistema Multidimensional para a Categorização de Comportamentos na Interação Terapêutica(SiMCCIT). Perspectivas em análise do comportamento, 2(1), 25-45.

Recibido: 18 de mayo, 2016 Revisado: 10 de febrero. 2017 Aceptado: 13 de febrero, 2017 


\section{APPENDIX}

\section{TERMO DE CONSENTIMENTO LIVRE E ESCLARECIDO}

Nome da pesquisa: Análise da interação terapêutica em terapia comportamental Pesquisador responsável: Vagner Angelo Garcia

Informações dadas aos respondentes: Estamos realizando uma pesquisa sobre a interação terapêutica em intervençôes com universitários que participaram anteriormente de uma intervenção que promoveu habilidades sociais. Os participantes desta pesquisa contribuirão autorizando o uso das filmagens das sessões realizadas durante a intervenção da pesquisa intitulada "Avaliação de um treinamento de habilidades sociais para estudantes universitários". Informamos que os participantes não terăo quaisquer despesas ao participarem desta pesquisa. Os participantes têm liberdade de se recusar a participar, de não responder a alguma pergunta e de retirar seu consentimento, a qualquer momento, caso alguma coisa lhes desagrade, sem qualquer problema para eles. Esta pesquisa fornecerá informaçôes importantes para futuras intervençóes com universitários e assim, os participantes estarão ajudando outros estudantes no futuro. Eu, enquanto pesquisador responsável pelo projeto, estou compromissado com o Código de Ética Profissional do Psicólogo, assegurando total sigilo quanto aos dados obtidos durante a pesquisa.

$\mathrm{Eu}$

RG abaixo assinado, estou ciente de que faço parte de uma amostra de pesquisa sobre a análise da interaçáo terapêutica em uma intervenção com universitários. Contribuirei autorizando o uso das filmagens das sessōes de atendimento. Declaro estar ciente: a) do objetivo do projeto; b) da segurança de que não serei identificado e de que será mantido caráter confidencial das informaçôes relacionadas com minha privacidade e c) de ter a liberdade de recusar a participar da pesquisa.

Data,

Assinatura do participante

Pesquisador responsável 